\title{
Live Fast and Die Young: Metal Effects on Condition and Physiology of Wild Yellow Perch from along Two Metal Contamination Gradients
}

\author{
Patrice Couture $^{1}$ and Greg Pyle ${ }^{2}$ \\ ${ }^{1}$ Institut National de la Recherche Scientifique, Centre Eau, Terre et \\ Environnement, QC, Canada; ${ }^{2}$ Department of Biology, Nipissing University, \\ North Bay, ON, Canada
}

\begin{abstract}
This review summarizes some of the main findings of our work with the Metals in the Environment Research Network examining seasonal and regional effects on metal accumulation, growth, condition, and physiology in wild yellow perch (Perca flavescens) from 10 lakes comprising two metal contamination gradients in the industrial regions of Sudbury, Ontario and Rouyn-Noranda, Québec, Canada. The specific objectives of this review are: (1) to propose threshold tissue metal concentrations to discriminate between fish from contaminated and reference sites; (2) to identify factors that can influence metal accumulation and fish condition; and (3) to define an experimental approach for measuring metal effects in wild yellow perch. Using tissue thresholds appeared useful not only for discriminating fish from clean or contaminated environments, but also provided a simple approach to examine metabolic consequences of tissue metal accumulation. Overall, fish from Sudbury grew faster, expressed higher aerobic capacities, and died younger, but also appeared better at limiting accumulation of some metals than Rouyn-Noranda fish. The condition of the latter fish was clearly more affected by metals than Sudbury fish. Finally, our dataset allows us to propose that yellow perch are highly suitable for ecological risk assessment studies of metal effects in wild fish, but that fish size, season, and region must be considered in sampling design and that several reference sites must be studied for meaningful conclusions to be reached.
\end{abstract}

Key Words: wild yellow perch (Perca flavescens), seasonal and regional variation, tissue metal concentration thresholds, metabolic enzyme activity, longevity, fish condition.

Address correspondence to Patrice Couture, Institut National de la Recherche Scientifique, Centre Eau, Terre et Environnement, 490 rue de la Couronne, Québec, QC, Canada G1K 9A9. E-mail: patrice_couture@ete.inrs.ca 


\section{P. Couture and G. Pyle}

\section{INTRODUCTION}

The field-based research reviewed here was conducted on yellow perch (Perca flavescens), a species of fish that has not received the attention it deserves in ecological risk assessment (ERA) of metal contamination in North American freshwater systems. Yellow perch is a freshwater-only percid distributed widely across North America. In Canada, it occurs naturally in every province except Newfoundland. It is found as far north as the Great Slave Lake and its distribution extends south to Ohio and Illinois. Its occurrence in most of the areas in Canada where mining and smelting activities take place makes it one of the most relevant fish to examine in metals ERA. The preferred habitat of yellow perch is lakes and ponds of all sizes, as well as rivers and creeks, but it avoids areas where significant currents are present. Therefore, this species is a less appropriate choice when impact sites of mining effluent release are situated in small creeks, but an ideal choice in lakes contaminated by these creeks. Yellow perch feed in shallow, vegetated areas. The young are planktivorous, but will rapidly incorporate increasing amounts of benthic invertebrates and eventually small fish as they grow. Therefore, dietary metal uptake, effects and risk could vary depending on fish size. Yellow perch reproduction takes place in early spring around the time of ice breakup, which in Sudbury and Rouyn-Noranda occurs in April (unpublished data). This is an important advantage over other species of small fish such as minnows, which typically breed during summer, because reproduction and associated changes in energy allocation and behavior could bias the responses of fish to metal contamination, making it inappropriate to carry out sampling around the reproductive period.

Contrary to other fish species co-existing in cleaner lakes, the yellow perch is commonly the only species still present in the most metal-contaminated lakes. For example, in the mid 1990s, yellow perch was the only species present in Hannah Lake and a dominant species in Whitson Lake, the two most contaminated Sudbury lakes included in this review (unpublished data). These lakes are rapidly recovering and today, brown bullhead (Ameiurus nebulosus), pumpkinseed (Lepomis gibbosus), and various minnows can be captured in Hannah Lake, while Whitson Lake also shelters a growing population of northern pike (Esox lucius) and walleye (Sander vitreus; unpublished data). Yellow perch is also a dominant species in metal-contaminated lakes of Rouyn-Noranda (Sherwood et al. 2000).

There is extensive literature, a review of which is beyond the scope of this article, indicating that natural abiotic (temperature, environmental chemistry) and biotic factors (reproduction, competition, predation, parasitism, food web productivity) influence condition and contaminant uptake in fish. However, our knowledge of factors influencing metal accumulation and condition in wild yellow perch is more limited, and warrants a brief review.

Several studies have reported that yellow perch tissue metal concentrations are influenced by environmental contamination (Brodeur et al. 1997; Laflamme et al. 2000; Levesque et al. 2002; Campbell et al. 2003; Couture and Rajotte 2003; Pyle et al. 2005; Couture et al. 2008a). A number of reports also indicate that metal-contaminated wild yellow perch suffer a range of metabolic and energetic impairments, including an impaired cortisol stress response (Hontela et al. 1996; Brodeur et al. 1997; Laflamme et al. 2000; Lacroix and Hontela 2004), bioenergetics (Sherwood et al. 


\section{Metal Effects on Condition and Physiology of Wild Yellow Perch}

2000; Sherwood et al. 2002), intermediary metabolism (Levesque et al. 2002), aerobic metabolism (Rajotte and Couture 2002; Audet and Couture 2003; Couture and Kumar 2003), and even basic morphometric condition indicators (Laflamme et al. 2000; Levesque et al. 2002; Pyle et al. 2005; Couture et al. 2008b). Although this substantial literature leaves little doubt that metals affect the condition of wild yellow perch, natural variations in fish condition likely confound interpretation of most indicators of yellow perch health. Limited sample size, small number of study sites, and single sampling events also limit application of these studies. Three studies have reported seasonal variations within a year in yellow perch tissue metal concentrations and condition. Two of them (Eastwood and Couture 2002; Kraemer et al. 2006b) examined seasonal variations in four or five lakes within a single region, and only examined the condition factor as an indicator of yellow perch health. The third (Audet and Couture 2003) focused on only two lakes from the Sudbury area but also examined variations in metabolic capacities. These combined studies indicate that both tissue metal concentrations and condition vary seasonally in yellow perch. Yet in order to better understand the implications for ERA of seasonal variations in condition and tissue metal concentrations, a larger study was required.

Here we review work that our group has conducted on tissue metal accumulation patterns and effects on both morphometric (growth, condition factor) and physiological (tissue protein contents and metabolic enzyme activities) condition in yellow perch from two of the most metal contaminated gradients of lakes in Canada (Sudbury (S), Ontario and Rouyn-Noranda (RN), Québec). We designed a large study in which 120 yellow perch of all sizes available from each of 5 lakes in each region (James (S1), Geneva (S2), Crowley (S3), Whitson (S4) and Hannah (S5) in Sudbury and Opasatica (RN1), Ollier (RN2), Bousquet (RN3), Osisko (RN4) and Dufault (RN5) in Rouyn-Noranda; see Couture et al. 2008a for information on these lakes including location, water quality and metal contamination levels) were sampled once in late spring and once in late summer. Morphometric indicators were recorded for all fish, and a subset of each age class was further analyzed for tissue metal concentrations and indicators of metabolic capacities. The resulting database is the largest of its kind, with morphometric parameters (length, mass, age, condition factor) available for 2400 fish. Liver and kidney enzyme activities and metal concentrations (the latter also measured in gut contents) are available for 400 of these fish of all age classes. The dataset generated is available through the MITE website (http://www.mithern.org/ mite_rn/research/Results-Details.asp?MetaDataID =6). Details of this research are published separately (Pyle et al. 2008; Couture et al. 2008a; Couture et al. 2008b).

The general objective of this research was to improve the ecological relevance of ERA by studying a fish species (yellow perch) that is not commonly considered under the current ERA paradigm but is widely distributed throughout North America and is known to inhabit many of the metal-contaminated environments around northern industrial regions. The specific objectives of this review are: (1) to propose thresholds for identifying above-normal accumulation of metals in yellow perch tissues; (2) to identify the factors that influence yellow perch metal contamination and condition; and (3) to define the experimental approach for fairly measuring metal effects in wild yellow perch. 


\section{P. Couture and G. Pyle}

\section{TISSUE METAL ACCUMULATION AS AN INDICATOR OF EXPOSURE}

\section{Thresholds of Reference Values}

Our studies to date have focused on five metals $(\mathrm{Cd}, \mathrm{Cu}, \mathrm{Ni}, \mathrm{Se}$, and $\mathrm{Zn})$ in the mining and smelting areas of Sudbury and Rouyn-Noranda. Because these metals all occur naturally, their presence can theoretically be detected in the tissues of all yellow perch, regardless of environmental contamination. Even though we have noted and reported important seasonal variations in yellow perch tissue metal concentrations (reviewed later), the ranges within which they fluctuate in clean lakes have upper thresholds efficiently separating them from values in contaminated fish for Cd and $\mathrm{Cu}$, but not for $\mathrm{Ni}$. This approach could not be used for Se for which water concentrations were not determined in several lakes (below analytical detection limits), and was irrelevant for $\mathrm{Zn}$, which is strongly regulated and weakly affected by environmental contamination (Couture et al. 2008a). To determine these upper thresholds of normal variation, all available data from clean sites should be used. In this review, the tissue metal-concentration thresholds that we proposed were exceeded by $10 \%$ of the reference fish in 5 to 7 lakes depending on the metal (in 200 to 300 fish) in 2 seasons (spring and summer). The value of $10 \%$ was selected as high enough to capture the natural variability in clean fish (whereas $20 \%$ could not), while avoiding the inclusion of uncommonly high values found on occasion even in clean fish (which would be included using $5 \%$ ). It should be emphasized that the value of $10 \%$ proposed here, although generating threshold concentrations in agreement with published literature, was based on our dataset and must be validated empirically in other datasets. Tissue metal concentrations measured in fish from contaminated lakes (exceeding the Ontario Provincial Water Quality Objectives [OPWQO], see Table 1) were then compared to the thresholds determined in clean fish. In cases where the majority of contaminated fish exceeded the $10 \%$ threshold in clean fish, we propose that (1) fish from these lakes are at a risk of toxicity; and (2) the use of thresholds for a specific metal and tissue could be useful for ERA. From an ERA perspective, measuring tissue metal concentrations in exposed fish and comparing them to threshold values has the advantage of providing a more direct measure of exposure and risk of toxicity than measuring contaminant concentrations in the different media from which the contaminant may be obtained (water, fish food items).

Below, we present evidence from empirical measurements in support of our suggestion that exceeding these thresholds may be linked to toxic effects in wild yellow perch. However, direct experimental evidence will be required to validate our hypothesis and, therefore, our thesis is limited to the reasonable suggestion that exceeding these tissue metal thresholds represents a risk of toxicity. Also, although metal speciation in water and food, as well as water chemistry in the case of aqueous metal uptake and subcellular partitioning for food-borne metals, are known to influence accumulation in fish tissues, the influence of these factors is complex and not fully understood. In the system studied, because inter-lake variations in water chemistry and their potential influence on differential tissue metal accumulation among fish populations remained small (Couture et al. 2008a), we have chosen to ignore these factors. Nonetheless, we cannot exclude that some of the regional differences 


\section{Metal Effects on Condition and Physiology of Wild Yellow Perch}

Table 1. Upper thresholds of kidney and liver $\mathrm{Cd}, \mathrm{Cu}$, and $\mathrm{Ni}$ concentrations ( $\mu \mathrm{g} / \mathrm{g}$ dry weight) exceeded by $10 \%$ of yellow perch in clean lakes from Sudbury and Rouyn-Noranda in spring and fall combined. Lakes were classified as clean when aqueous concentrations of $\mathrm{Cd}, \mathrm{Cu}$ or Ni were below the Ontario Provincial Water Quality Objective (Ontario Ministry of Environment and Energy (OMEE) 1994) of 0.1, 5 , and $25 \mu \mathrm{g} / \mathrm{L}$, respectively.

\begin{tabular}{|c|c|c|c|c|}
\hline Metal & $\begin{array}{l}\text { Clean } \\
\text { lakes }\end{array}$ & $\begin{array}{c}\text { Upper } \\
10 \% \text { threshold } \\
\text { in clean fish }\end{array}$ & $\begin{array}{l}\% \text { above threshold } \\
\text { in pooled } \\
\text { contaminated fish }\end{array}$ & $\begin{array}{c}\% \text { above } \\
\text { above threshold } \\
\text { per lake }\end{array}$ \\
\hline \multicolumn{5}{|c|}{ Kidney } \\
\hline \multirow[t]{5}{*}{$\mathrm{Cd}$} & RN1-2-3; S1-2 & $19.9(211)$ & $68.3 \%(186)$ & RN4: $32.5 \%$ \\
\hline & & & & RN5: $92.2 \%$ (51) \\
\hline & & & & S3: 67.5\% (40) \\
\hline & & & & S4: $90.9 \%(22)$ \\
\hline & & & & S5: 60.6\% (33) \\
\hline \multirow[t]{5}{*}{$\mathrm{Cu}$} & RN1-2-3; S1-2 & $20.2(202)$ & $31.2 \%(167)$ & RN4: $74.2 \%$ (31) \\
\hline & & & & RN5: $27.5 \%$ (51) \\
\hline & & & & S3: 16.7\% (36) \\
\hline & & & & S4: $35.0 \%(20)$ \\
\hline & & & & S5: 6.9\% (29) \\
\hline \multirow[t]{3}{*}{$\mathrm{Ni}$} & RN1-2-3-4-5; S1-2 & 14.4 (259) & $17.9 \%(84)$ & S3: $18.9 \%$ (37) \\
\hline & & & & S4: $29.4 \%$ (17) \\
\hline & & & & S5: $10.0 \%(30)$ \\
\hline \multicolumn{5}{|l|}{ Liver } \\
\hline \multirow[t]{5}{*}{ Cd } & RN1-2-3; S1-2 & $11.0(207)$ & $72.6 \%(175)$ & RN4: $53.3 \%(45)$ \\
\hline & & & & RN5: $100 \%(51)$ \\
\hline & & & & S3: $55.2 \%$ (29) \\
\hline & & & & S4: $57.9 \%$ (19) \\
\hline & & & & S5: $68.4 \%(31)$ \\
\hline \multirow[t]{5}{*}{$\mathrm{Cu}$} & RN1-2-3; S1-2 & $38.8(207)$ & $72 \%(164)$ & RN4: $75.6 \%(45)$ \\
\hline & & & & RN5: $78.4 \%(51)$ \\
\hline & & & & S3: 45.5\% (22) \\
\hline & & & & S4: $68.4 \%$ (19) \\
\hline & & & & S5: 77.8\% (27) \\
\hline \multirow[t]{3}{*}{$\mathrm{Ni}$} & RN1-2-3-4-5; S1-2 & $12.1(296)$ & $8.3 \%(72)$ & S3: 0\% (21) \\
\hline & & & & S4: $9.1 \%$ (22) \\
\hline & & & & S5: $13.8 \%$ (29) \\
\hline
\end{tabular}

Refer to Couture et al.(2007a) for water metal concentrations in each lake. The proportion (in \%) of fish from contaminated lakes with tissue concentrations above the threshold is indicated for all contaminated fish pooled, and for fish from each contaminated lake (sample size in parentheses). Contaminated lakes were those not considered as clean (metal-specific) among Sudbury (S1 to S5) and Rouyn-Noranda (RN1 to RN5) lakes. 


\section{P. Couture and G. Pyle}

in metal accumulation, which we attribute to selection, may be partly explained by abiotic factors such as water chemistry.

Tissue Cd concentrations in all samples examined in Couture et al. (2008a) ranged from 0.3 to $178 \mu \mathrm{g} / \mathrm{g} \mathrm{dw}(n=397)$ and from 0.1 to $77 \mu \mathrm{g} / \mathrm{g} \mathrm{dw}(n=382)$ in kidney and liver, respectively (data not shown). The thresholds proposed for Cd of $19.9 \mu \mathrm{g} / \mathrm{g} \mathrm{dw}$ in kidney and $11.0 \mu \mathrm{g} / \mathrm{g} \mathrm{dw}$ in liver (Table 1) appear highly useful at separating clean from Cd-contaminated fish, with $10 \%$ of reference fish above the thresholds, and about $70 \%$ of contaminated fish from both regions combined above the thresholds, for both liver and kidney. These results support conclusions in Couture et al. (2008a) that fish from both regions are incapable of regulating Cd. Finally, the proportion of fish from contaminated lakes above the threshold Cd concentration was higher in the most Cd-contaminated lakes (RN5 and S4) compared to lakes classified as $\mathrm{Cd}$-contaminated but where aqueous $\mathrm{Cd}$ concentrations were intermediate between the most Cd-contaminated lakes and reference lakes. We propose that the proportion of fish with liver and kidney Cd concentrations above thresholds could be used as an indicator of risk for Cd toxicity at the population level. Although a threshold for discriminating between clean and Cd-contaminated yellow perch has never been proposed for kidney, for liver the value of $11 \mu \mathrm{g} / \mathrm{g} \mathrm{dw}$ proposed here is in strong agreement with a value of $10 \mu \mathrm{g} / \mathrm{g} \mathrm{dw}$ proposed earlier (Couture and Rajotte 2003).

Tissue Cu concentrations in all samples examined in Couture et al. (2008a) ranged from 0.2 to $171 \mu \mathrm{g} / \mathrm{g} \mathrm{dw}$ and from 0.1 to $1078 \mu \mathrm{g} / \mathrm{g} \mathrm{dw}$ in kidney and liver, respectively (data not shown). Although the liver $\mathrm{Cu}$ threshold value of $38.8 \mu \mathrm{g} / \mathrm{g} \mathrm{dw}$ proposed here efficiently discriminates clean from Cu-contaminated fish with $72 \%$ of the latter yielding liver $\mathrm{Cu}$ concentrations above this threshold, the threshold for kidney above which $10 \%$ of fish from Cu-clean lakes are found would not allow discriminating clean from contaminated fish, as only about $30 \%$ of the latter expressed values above the threshold of $20.2 \mu \mathrm{g} / \mathrm{g} \mathrm{dw}$. This suggests that kidney $\mathrm{Cu}$ is more strongly regulated than liver $\mathrm{Cu}$, and highlights the role of liver for $\mathrm{Cu}$ storage as well as the essential and tightly-regulated nature of this metal. As for $\mathrm{Cd}$, a higher proportion of fish were above thresholds in the most Cu-contaminated lakes (RN5, S4, and S5) but in liver only. Therefore, we propose that the proportion of fish with liver $\mathrm{Cu}$ concentrations above thresholds could be used as an indicator of risk for $\mathrm{Cu}$ toxicity at the population level. Finally, the value of $38.8 \mu \mathrm{g} / \mathrm{g}$ dw proposed for liver is about $20 \%$ lower than the value of 50 proposed earlier (Couture and Rajotte 2003) and supported by other research (Kraemer et al. 2006b).

Tissue Ni concentrations in all samples examined in Couture et al. (2008a) ranged from lower than 0.1 to 81 or $89 \mu \mathrm{g} / \mathrm{g} d \mathrm{~d}$ in kidney and liver, respectively (data not shown). In contrast to $\mathrm{Cd}$ and $\mathrm{Cu}$, the thresholds of both liver and kidney $\mathrm{Ni}$ concentrations above which $10 \%$ of fish from Ni-clean environments fell was not useful in discriminating between fish from high vs. low aqueous Ni concentrations, because only 8 to $18 \%$ of fish from Ni-rich environments were above these threshold values (Table 1). This odd result is due to exceptionally high tissue Ni concentrations in fish from $\mathrm{RN}$ in the spring, even though all $\mathrm{RN}$ lakes were classified as low$\mathrm{Ni}$ (Couture et al. 2008a). As discussed in Couture et al. (2008a), it appears that Sudbury yellow perch can better regulate their tissue Ni concentrations than RN fish. Therefore, also in contrast with $\mathrm{Cd}$ and $\mathrm{Cu}$, even though a threshold of tissue 


\section{Metal Effects on Condition and Physiology of Wild Yellow Perch}

Ni concentrations could be proposed for S yellow perch, it could not be applied to RN fish in the spring, as fish from these Ni-clean environments would exceed the threshold. As for $\mathrm{Cd}$ and $\mathrm{Cu}$, ongoing investigations are attempting to establish whether fish tissue $\mathrm{Ni}$ concentrations that exceed these tissue metal accumulation thresholds will result in toxicity. Some of the evidence in support of this hypothesis is reviewed in the following sections.

\section{SEASONAL VARIATIONS IN TISSUE METAL CONCENTRATIONS AND IMPLICATIONS FOR ERA}

Several studies have reported that yellow perch tissue metal concentrations vary seasonally, in contaminated lakes (Eastwood and Couture 2002; Audet and Couture 2003; Kraemer et al. 2006b) but also sometimes in clean lakes (data examined later from Couture et al. 2008a). Here we provide evidence with implications for ERA of how ignoring these seasonal variations could falsely lead to conclusions that fish from contaminated lakes do not differ in tissue metal concentrations compared to clean fish.

In the first example, lake RN2, with an aqueous Cd concentration of $0.03 \mu \mathrm{g} / \mathrm{L}$ (Couture et al. 2008a), is considered clean with respect to Cd contamination, whereas RN4 is considered contaminated (Table 1). In spring, kidney Cd concentrations were higher in fish from RN4 compared to fish from RN2 (Figure 1). However, if sampling was carried out in both lakes in summer, or if RN2 was sampled in the spring and RN4 in summer, we would conclude that kidney Cd concentrations did not differ between these fish, and therefore that RN4 fish do not face a higher risk of Cd toxicity than clean fish. Thus, based on a statistical comparison of kidney Cd concentrations, a higher risk for RN4 fish could only be detected in spring. Using the $10 \%$ upper threshold approach described above of $19.9 \mu \mathrm{g} / \mathrm{g} \mathrm{dw}$ for kidney Cd (Table 1) and applying it to concentrations measured in RN2 and RN4 fish, 32 to $33 \%$ of RN4 fish, but only 4 to $8 \%$ of RN2 fish fell above the threshold,

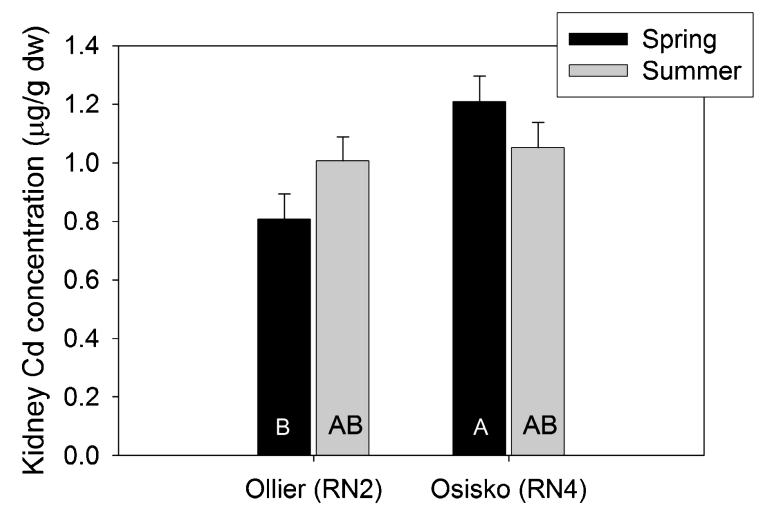

Figure 1. Mean log kidney Cd concentrations (+SEM) in spring and summer in a Cd-clean lake (RN2) and in a Cd-contaminated lake (RN4). Bars sharing the same letters are not significantly different from one another (two-way ANOVA; $p>.05)$. 


\section{P. Couture and G. Pyle}

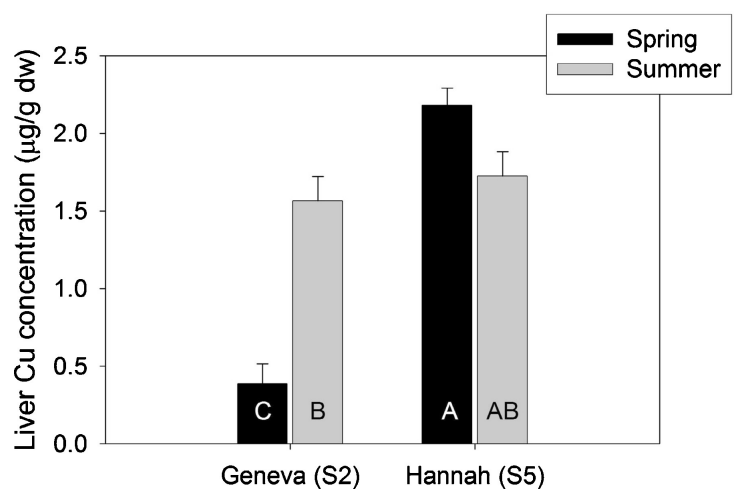

Figure 2. Mean log liver Cu concentrations (+SEM) in spring and summer in a Cu-clean lake (S2) and in a Cu-contaminated lake (S5). Bars sharing the same letters are not significantly different from one another (two-way ANOVA; $p>.05)$.

in spring and summer, respectively. Combining these approaches of sampling two seasons and using concentration thresholds for comparison, we can conclude that yellow perch from RN4 face a higher risk of Cd toxicity compared to reference fish in both seasons, but that differences between clean and contaminated fish are more important in spring. Given that only a third of fish from RN4 exceeded the threshold of kidney $\mathrm{Cd}$ at any time, we could also propose that the risk of Cd toxicity is moderate.

Similarly, we compared liver $\mathrm{Cu}$ concentrations in fish from one Cu-clean lake (S2) and one contaminated lake (S5) (Figure 2). Liver Cu was higher in S5 compared to $\mathrm{S} 2$, but only in spring, because of a major increase in liver Cu in S2 fish in summer. Interestingly, while $0 \%$ of $\mathrm{S} 2$ fish were above the liver $\mathrm{Cu}$ threshold reported in Table 1 in the spring, in summer $44 \%$ of fish from this clean lake exceeded the threshold. In comparison, there was $83 \%$ and $67 \%$ of S5 fish above the threshold in spring and summer, respectively. Combined, these analyses suggest that $\mathrm{S} 5$ fish constantly face a high risk of $\mathrm{Cu}$ toxicity as the majority of them sustain liver $\mathrm{Cu}$ concentrations higher than $90 \%$ of values in clean fish, but that nearly half of S2 fish, although living in a lake low in aqueous $\mathrm{Cu}$, may also have to face the metabolic consequences of excess liver $\mathrm{Cu}$ in summer.

Although only two concrete examples have been provided, comparing fish from other clean lakes with fish from other contaminated lakes in our database, or performing these comparisons with the other metals $(\mathrm{Ni}$, Se and $\mathrm{Zn}$ ) for which yellow perch showed seasonal variations in tissue concentrations (Couture et al. 2008a), would similarly support that sampling fish from all study lakes within a narrow time window and more than once a year is required for determining whether tissue metal accumulation represents a risk to fish. Because seasonal variations in tissue metal concentrations are inconsistent among metals and lakes and between the two regions studied, no recommendation of a better season for maximizing differences between fish from clean and contaminated lakes can be made. 


\section{Metal Effects on Condition and Physiology of Wild Yellow Perch}

\section{REGIONAL DIFFERENGES IN TISSUE METAL ACGUMULATION AND IMPLICATIONS FOR ERA}

Yellow perch from different regions sometimes differ widely in their accumulation of metals from environments having the same degree of metal contamination. Several studies have shown that, regardless of region (Sudbury or Rouyn-Noranda), yellow perch cannot regulate tissue $\mathrm{Cd}$. As a result, yellow perch from both regions demonstrate similar patterns of tissue $\mathrm{Cd}$ accumulation when exposed to either dietary or waterborne sources (Giguere et al. 2004; Kraemer et al. 2006a; Couture et al. 2008a). Consequently, when studying Cd contamination, the distance between reference and contaminated lakes may not be as important as for $\mathrm{Ni}$, because $\mathrm{S}$ fish may have evolved superior Ni-regulatory capacities than RN fish. Although a broad statistical approach has already described this general phenomenon (Couture et al. 2008a), this case study allows us a better understanding of the implications for ERA.

We compared mean liver and kidney Ni concentrations in the spring in fish from two lakes (RN3 and S1) with similarly low aqueous $(1.2 v s .0 .9 \mu \mathrm{g} / \mathrm{L}$, or 1.3 -fold higher in RN3) and dietary (6.7 vs. $3.9 \mu \mathrm{g} / \mathrm{g} \mathrm{dw}$, or 1.7-fold higher in RN3) Ni concentrations. Liver Ni concentration was 11.1-fold higher in RN3 compared to S1 fish (15.6 vs. $1.4 \mu \mathrm{g} / \mathrm{g} \mathrm{dw}$ ), and kidney Ni concentration was 7.9-fold higher in RN3 compared to S1 fish (15.6 vs. $1.4 \mu \mathrm{g} / \mathrm{g} \mathrm{dw}$ ). Comparing fish tissue concentrations in spring in RN4 vs. S2 lakes, both with similarly low aqueous and dietary $\mathrm{Ni}$ exposure for yellow perch, also suggested much greater Ni-accumulation in $\mathrm{RN}$ fish (1.9-fold and 10.5-fold in liver and kidney, respectively). Some of the tissue $\mathrm{Ni}$ concentrations measured in $\mathrm{RN}$ fish were in the same range as the highest values recorded in $\mathrm{S}$ fish. Comparisons in high-Ni lakes from both regions could not be performed due to the absence of such lakes in $\mathrm{RN}$, but we can only speculate on the tissue $\mathrm{Ni}$ concentrations that would be reached if $\mathrm{RN}$ fish were subjected to the high dietary and aqueous $\mathrm{Ni}$ exposure faced by $\mathrm{S}$ fish. We could not apply the threshold approach to a pooled sample of fish from both regions owing to the high tissue Ni concentrations in low-Ni lakes in RN (see earlier). Therefore, it is clear, at least for $\mathrm{Ni}$, that tissue concentrations do not reflect risk based on aqueous and dietary exposure in $\mathrm{RN}$ fish. However, tissue-Ni accumulation patterns in $\mathrm{S}$ fish more predictably reflected environmental concentrations (data reported in Couture et al. 2008a).

We have discussed elsewhere the regional differences in metal accumulation between yellow perch from Sudbury and Rouyn-Noranda. (Couture et al. 2008a) and proposed that selective pressures may have allowed $\mathrm{S}$ fish to evolve better capacities for regulating $\mathrm{Ni}, \mathrm{Cu}$, and perhaps also Se compared to $\mathrm{RN}$ fish. Therefore, when studying metal exposure and accumulation patterns in wild fish, it is best to select reference sites that are situated in reasonably close proximity to metal-contaminated sites to allow for a reasonable assumption of relatively close genetic similarity among comparative populations, when it cannot be tested. Testing differences in tissue metal accumulation in genetically distant fish may be meaningless from an ERA perspective. 


\section{P. Couture and G. Pyle}

\section{EFFECTS OF SIZE AND AGE ON METAL ACGUMULATION}

There is no controversy, and an abundant literature, on the bioaccumulation of several organic contaminants over time in fish. Among metals, the organic form of $\mathrm{Hg}\left(\mathrm{CH}_{3} \mathrm{Hg}\right)$ is well known to accumulate in older fish, including yellow perch (Ion et al. 1997). However, evidence of accumulation of inorganic forms of metals remains anecdotal and the literature contains limited, and sometimes contradictory, evidence. Literature on metal accumulation in fish in general and specifically in yellow perch has been reviewed elsewhere (Sorensen 1991; Couture et al. 2008a). The overwhelming evidence from these reviews is that inorganic metals do not generally accumulate in fish over time, except for anecdotal reports including two studies indicating that $\mathrm{Cd}$ accumulates with size in yellow perch from RN4 (Giguère et al. 2004) and other RN lakes (Couture et al. 2008a). However, in spite of an absence of a general pattern of increasing or decreasing tissue metal concentrations with size in yellow perch, in each individual lake and depending on the season, tissue metal concentrations $(\mathrm{Cd}, \mathrm{Cu}, \mathrm{Ni}, \mathrm{Se}$, and $\mathrm{Zn})$ are sometimes correlated with size, either positively or negatively (Couture $e t$ al. 2008a). Yellow perch tissue metal concentrations have been shown by several studies (briefly reviewed in the Introduction) to be strongly influenced by environmental contamination but not consistently by size, implying that tissue metal concentrations are largely the reflection of both recent (because they vary seasonally) accumulation from aqueous and dietary sources and depuration (Kraemer et al. 2005). From an ERA perspective, if size or age did not affect fish tissue metal concentrations, fish size could be ignored in the sampling design and data interpretation. On the other hand, if accumulation patterns with size were consistent, models could be used to correct the effects of size on tissue metal concentrations. However, because neither of these scenarios appears to reflect the reality in the field, careful size selection must be considered in metals ERA studies with yellow perch.

\section{MORPHOMETRIC AND PHYSIOLOGICAL CONDITION}

\section{Morphometric Fish Condition}

Fish condition is commonly assessed by environmental scientists who wish to evaluate the general "well-being" of fish in a specific population. Condition is typically estimated as a ratio of the actual weight of a fish against an expected weight estimated from a double-log plot of fish weight and length from fish sampled from a population of interest (for a detailed discussion about traditional fish condition metrics, see Pyle et al. 2008). This kind of condition metric, which we shall refer to as "morphometric condition" hereafter, is thought to reflect recent feeding activities in sampled fishes. Fish assessed to be of high condition are heavy relative to their length, which corresponds to increased energy storage (i.e., fat deposition) from abundant food resources relative to physiological energetic requirements. In contrast, low-condition fish deposit less fat because of reduced food availability and (or) increased physiological demand for energetic resources, which may be the case in metal-contaminated systems where fish allocate significant energetic resources toward metal detoxification (Smith et al. 2001). Therefore, fish morphometric condition is often used 


\section{Metal Effects on Condition and Physiology of Wild Yellow Perch}

in ERAs to provide a rough approximation of the relationship between available resources (i.e., food availability and possibly food quality) and a fish's energetic demand.

From the aforementioned, it seems intuitive that fish inhabiting metalcontaminated environments are likely to be of lower morphometric condition than those inhabiting clean environments. Fish allocate energetic resources to detoxify metals taken up through food or water, and the presence of relatively high environmental metal concentrations may reduce food availability if concentrations are high enough to induce toxicity in food organisms (Sherwood et al. 2000). However, published studies investigating morphometric condition in wild yellow perch populations have led to contradictory conclusions in the literature.

Several studies have concluded that fish inhabiting metal-contaminated lakes are of lower morphometric condition than those inhabiting reference lakes (Leis and Fox 1994; Laflamme et al. 2000; Lohner et al. 2001; Levesque et al. 2002; Rajotte and Couture 2002; Levesque et al. 2003; Bervoets and Blust 2003; Couture and Rajotte 2003). In contrast, other studies have reported higher morphometric condition in fish inhabiting metal-contaminated lakes relative to reference lakes (Farkas et al. 2003; Pyle et al. 2005). Therefore, based on the published literature, it is difficult to make any general statements about the relationship between metal contamination and morphometric condition in fish.

To illustrate this, we calculated relative condition $\left(K_{n}\right)$ in wild yellow perch from 10 lakes comprising 2 5-lake metal-contamination gradients. Data reported here are from Pyle et al. (2008). Relative condition is a slope-corrected condition factor, where slopes are derived from a double-log plot of fish weight ( $W$ in $g$ ) versus fish length ( $L$ in $\mathrm{mm}$ ) using the formula, $K_{n}=W / L^{s} \times 10$, where $s$ is the slope of the double-log plot. Slopes were calculated for each individual lake (regression details are in Table 2 ), and $K_{n}$ for each lake by season is reported in Figure 3.

In each metal-contamination gradient, we sampled two reference lakes, two metalcontaminated lakes, and one intermediate lake. Had we restricted our analysis to fewer lakes, we would not have been able to draw any meaningful conclusions with respect to the relationship between metal-contamination and fish condition. For example, if we had selected $\mathrm{S} 1$ as our only reference lake to compare $K_{n}$ against fish from the two most metal-contaminated lakes in the Sudbury region, S4 and S5 lakes, we may have concluded that fish from the contaminated lakes yielded lower condition than those from a reference lake (see Table 2 for statistical details). However, we could have just as appropriately selected S2 as our reference lake, and the conclusions we could draw would be vastly different: that is, fish from S5 were of significantly higher condition than those from S2, and fish from S4 showed no significant difference in $K_{n}$ relative to those from S2 (Table 2). A similar effect can be observed in Rouyn-Noranda lakes. For example, if we had selected RN1 as a reference lake, we would have concluded that there was no significant difference in $K_{n}$ between fish sampled from the reference lake and those from the most contaminated lakes RN4 and RN5. The only significant difference in $K_{n}$ between reference and contaminated fish is with fish from RN3, the intermediate lake, which had significantly lower condition than those from RN1 (Table 2). However, if we were to use RN2 as the reference lake, our conclusions would have been different. There was no significant difference in $K_{n}$ between fish sampled from RN2 and one of the 


\section{P. Couture and G. Pyle}

Table 2. Results of log-log weight (g)-length $(\mathrm{mm})$ analysis of covariance on wild yellow perch sampled from 10 lakes along two metal-contamination gradients in Rouyn-Noranda, Quebec and Sudbury, Ontario $(n=2449)$ to determine if slopes ( $b$; scaling coefficients, which are used in the calculation of $\left.K_{n}\right)$ varied by lake $\left(F_{1,9}=257964, p<.0001\right)$ or intra(Rouyn-Noranda: $F_{1,4}=154204, p<.0001$; Sudbury: $F_{1,4}=111820$, $p<.0001)$ or inter- $\left(F_{1,1}=237157, p<.0001\right)$ regionally.

\begin{tabular}{lllccc}
\hline Region & Lake & Code & Intercept (a) & Slope (b) & $K_{n}$ \\
\hline Rouyn-Noranda & Opasatica & RN1 & -5.24 & 3.13 & $1.09 \pm 0.36(240)^{b c}$ \\
& Ollier & RN2 & -5.31 & 3.18 & $1.15 \pm 0.35(236)^{b}$ \\
& Bousquet & RN3 & -5.43 & 3.25 & $0.86 \pm 0.49(169)^{d}$ \\
& Dufault & RN4 & -5.11 & 3.05 & $1.00 \pm 0.55(240)^{c}$ \\
Sudbury & Osisko & RN5 & -5.45 & 3.21 & $1.08 \pm 0.39(240)^{b c}$ \\
& James & S1 & -4.86 & 2.91 & $1.34 \pm 0.27(257)^{a}$ \\
& Geneva & S2 & -5.16 & 3.07 & $0.87 \pm 0.35(257)^{d}$ \\
& Crowley & S3 & -4.95 & 2.96 & $1.09 \pm 0.32(278)^{b c}$ \\
& Whitson & S4 & -5.05 & 3.00 & $0.80 \pm 0.42(254)^{d}$ \\
& Hannah & S5 & -5.32 & 3.15 & $1.00 \pm 0.30(278)^{c}$ \\
\hline
\end{tabular}

Mean $K_{n} \pm \mathrm{SD}(\mathrm{n})$ is provided for fish sampled from each lake. Lakes sharing the same alphabetical superscript in the $K_{n}$ column are not significantly different from one another (Tukey-Kramer HSD; $p>.05$ ). All slopes (except Whitson; $p=.92$ ) are significantly different from $3(p<.02)$.

most contaminated Rouyn-Noranda lakes, RN4. However, RN2 fish had significantly higher condition than those from RN3 and RN5 (Table 2).

Establishing seasonal trends in fish condition as a function of metal contamination is equally problematic (see Figure 3). In Rouyn-Noranda, fish from one of the reference lakes (RN1) showed significantly higher condition in the spring relative to the summer $(t=2.9, d . f .=219.1, p=.004)$, whereas there was no seasonal difference in the other reference lake (RN2; $t=-1.1, d . f .=234, p=.28)$. No seasonal differences were observed in any other Rouyn-Noranda lake $(p>.05)$. This situation is different than what was observed in Sudbury-area lakes. Both reference lakes in the Sudbury region (S1 and S2) yielded fish having higher condition in the summer than in the spring (S1: $t=-7.3, d . f .=231.2, p<.0001 ; \mathrm{S} 2: t=-2.5, d . f$. $=202.6, p=.01)$, a phenomenon also observed in one of the most contaminated Sudbury-area lakes, S5 $(t=-14.1, d . f .=221.9, p<.0001)$.

Another issue that must be considered when comparing fish from different populations is the statistical assumptions inherent in the estimation of commonly used fish condition metrics. Fulton's condition factor $\left(K_{F}\right)$ assumes that the slope of the $\log$-log fish weight-length plot is 3 , because $K_{F}$ is estimated as weight/length ${ }^{3}$. Of the 10 lakes that we sampled, only 1 (S4) yielded a slope that was not significantly different from 3 (Table 2). In every other lake, the slope was either significantly higher or lower than 3, violating a major assumption of the $K_{F}$ model. But even when slopes are used in the calculation of fish condition, such as the slope-corrected $K_{n}$, 


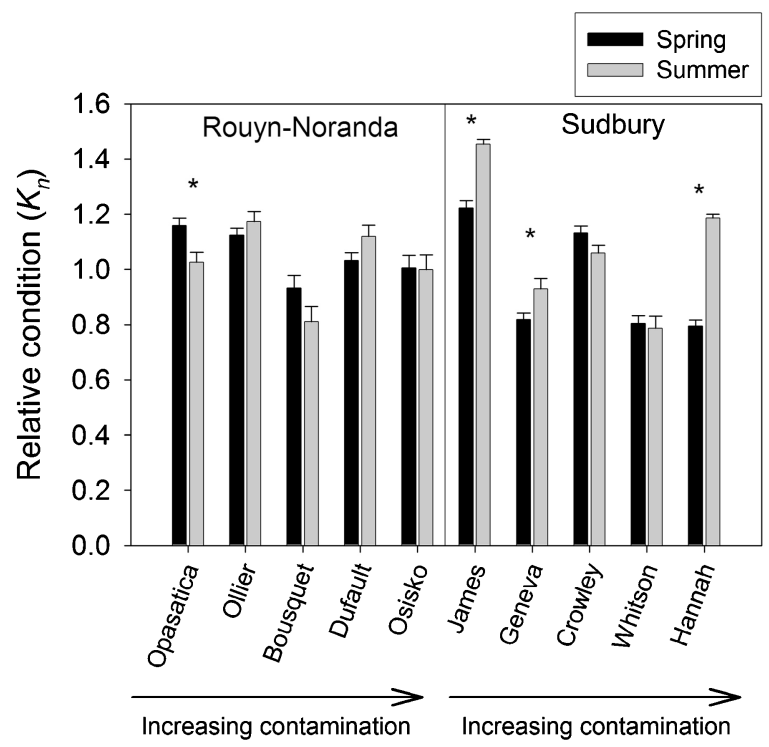

Figure 3. Effect of season on yellow perch relative condition $\left(K_{n}\right)$ in each study lake. Bars represent means + SEM $(n=75-148)$; asterisks $(*)$ indicate a significant difference between spring and summer $(t$-test; $p \leq .05)$.

which replaces 3 in the calculation with a scaling coefficient (i.e., the slope of the double-log plot), the model still assumes homogeneity of slopes among comparative populations (Cone 1989). Again, our analysis revealed that slopes varied among our comparative populations (Table 2), violating this statistical assumption.

These results indicate that common fish condition metrics, such as the Fulton's condition factor $\left(K_{F}\right)$ or the slope-corrected relative condition factor ( $K_{n}$, which we used here for illustrative purposes), can only provide a rough approximation of fish "well-being" at a particular place and time. Condition factor is an integrative metric that can be influenced by a number of abiotic (temperature, environmental conditions such as water quality or contamination, etc.) and biotic (predation pressure, competition, food availability, population genetics, etc.) factors. Therefore, it is difficult to draw any meaningful conclusions about fish condition if the full range of variability among comparative populations is not considered. This analysis resulted in similar confusing, and sometimes contradictory, conclusions as those reported in the literature. Consequently, a better approach to assessing fish condition is to sample a large number of fish representing the full size/age range in each population using more than one reference site, and optimally, over more than one season. Condition can be estimated using a least-squares approach, originally proposed by Le Cren (1951) and later modified by Patterson (1992). This is the approach we adopted for assessing the influence of environmental conditions on fish condition, which we reported in Pyle et al. (2008).

In Pyle et al. (2008), we speculated that fish from Rouyn-Noranda and Sudbury probably had significant genetic differences based largely around differences in observed growth patterns (e.g., see Figure 1 in Pyle et al. 2008). Those growth pattern 


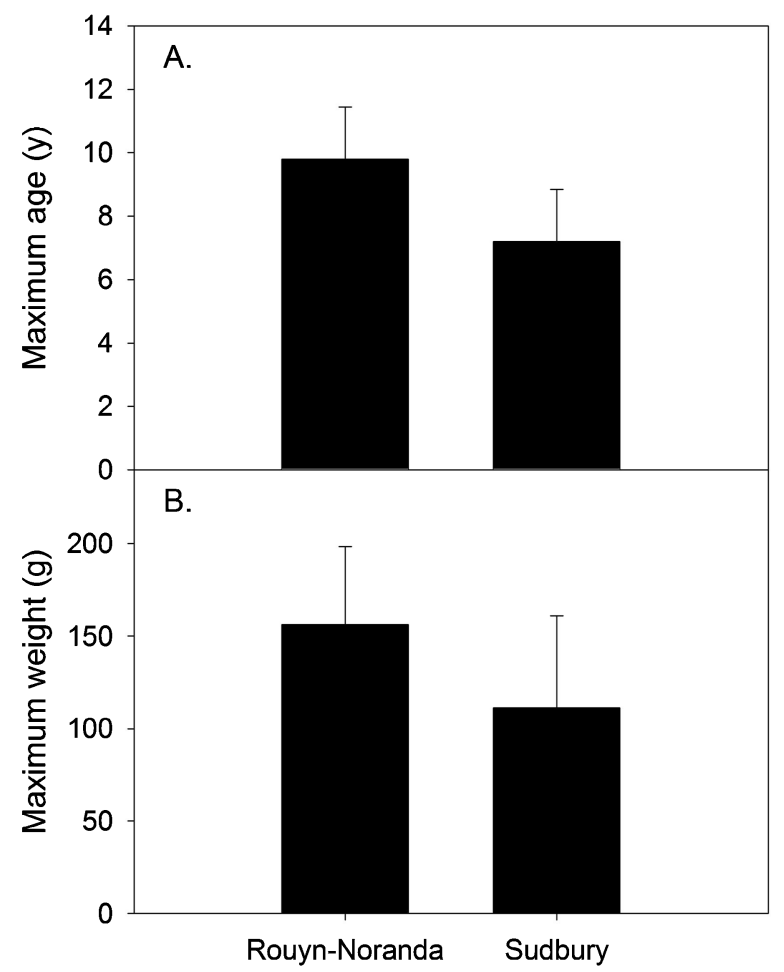

Figure 4. Mean maximum age $(\mathrm{A})$ and weight $(\mathrm{B})( \pm \mathrm{SD} ; n=5)$ in wild yellow perch collected from 10 lakes forming two 5-lake contamination gradients in Rouyn-Noranda, QC, and Sudbury, ON. Statistical comparisons were not attempted given that fish from each region were sampled in different years.

differences indicated that Rouyn-Noranda fish grew relatively quickly while they were young, but slowed as they approached maximum age (approx. 11 y). In Sudbury-area lakes, however, fish started out growing slowly, but then increased their growth rate until eventually slowing as they approached maximum age (approx. 9 y). At approximately $4 \mathrm{y}$ of age (i.e., when both groups of fish demonstrated their fastest growth rates) Sudbury-area fish grew significantly faster $(1.8 \mathrm{~g} / \mathrm{y})$ than Rouyn-Noranda fish $\left(1.7 \mathrm{~g} / \mathrm{y}\right.$; instantaneous slopes compared using ANCOVA, $\left.\mathrm{F}_{1,1817}=9282, p<.0001\right)$. The average maximum age of fish collected from the five lakes comprising the Rouyn-Noranda gradient was 9.8 y (range: 7-11 y), whereas in Sudbury it was 7.2 y (range: 5-9 y) (Figure 4). Similarly, maximum fish weight was $41 \%$ greater in RouynNoranda than in Sudbury (Figure 4). Using the least squares approach to estimate fish condition mentioned earlier, we also found that fish from Rouyn-Noranda were generally of higher condition than those from Sudbury (Pyle et al. 2008).

Therefore, Rouyn-Noranda fish were of higher condition, lived longer, grew to larger sizes, but grew slower (and demonstrated a different long-term growth pattern) than fish from Sudbury, regardless of environmental contamination in any specific lake. Together, these results suggest that fish from Sudbury and 


\section{Metal Effects on Condition and Physiology of Wild Yellow Perch}

Rouyn-Noranda probably derived from a different genetic heritage. Mitochondrial DNA haplotype analysis, as has been done on Ontario lake trout (Salvelinus namaycush) populations (Wilson and Hebert 1996 1998), would provide important insights on these population differences, which have important implications to ERA, because several of the measures it considers such as growth and metal handling capacities may have strong genetic influences.

\section{Metal Effects on Metabolic Enzyme Activities and Longevity}

To evaluate the physiological condition of the wild yellow perch we sampled from each of the 10 lakes comprising the two metal-contamination gradients, we measured total protein concentration, lactate dehydrogenase (LDH) (an indicator of anaerobic capacities), citrate synthase (CS), and cytochrome C oxidase (CCO) activities (indicators of aerobic capacities) in muscle and liver tissues. We reported regional and seasonal effects in Couture et al. (2008b). Here, we wanted to determine the extent to which total protein concentration or tissue enzyme activities varied on the basis of whether or not tissue metal concentrations were above or below metal accumulation thresholds reported in Table 1. In each region, we compared total protein concentration and tissue enzyme activities (in muscle and liver) between fish having tissue metal concentrations (in kidney or liver) above or below the metal accumulation thresholds. Results of this analysis are reported in Tables 3 (muscle enzymes) and (liver enzymes).

Exceeding tissue metal thresholds did not affect liver or muscle protein concentrations in Sudbury fish (Tables 3 and 4). In RN fish, however, whereas excess $\mathrm{Cu}$ (either in liver or kidney) negatively affected muscle protein concentrations, in contrast, exceeding tissue thresholds of $\mathrm{Cd}, \mathrm{Cu}$, or $\mathrm{Ni}$ yielded higher liver protein concentrations. Because elevated muscle protein concentration is an indicator of muscle energy reserves (Lambert and Dutil 1997), this finding highlights a regional difference in metal tolerance, with energy reserves of $\mathrm{RN}$ but not $\mathrm{S}$ fish being negatively affected by $\mathrm{Cu}$. Our data support that yellow perch are a metal-tolerant species, but that metal exposure exerts a metabolic cost that varies according to the region of origin of the fish. Specifically, the tissue metal threshold approach followed here indicates that RN fish exceeding these thresholds increase their liver protein concentration, presumably in an effort to combat metal intoxication (for example, by increasing their production of metallothioneins, Campbell et al. 2005), thus (at least when the $\mathrm{Cu}$ thresholds are exceeded) decreasing energy available for muscle growth. Implications for ERA are that tissue protein concentrations are useful indicators of metal stress in $\mathrm{RN}$, but not in $\mathrm{S}$, fish.

Evidence from the literature of metal effects on muscle and liver LDH activity is contradictory and complicated by a number of factors, including a lack of allometric corrections when comparing different-sized fish (Levesque et al. 2002), or studies limited to two lakes (Audet and Couture 2003). Two studies conducted in the Sudbury area have examined in more detail the relationships between tissue anaerobic capacities and metal contamination in yellow perch. In the first, Rajotte and Couture (2002) concluded that metal contamination did not affect yellow perch anaerobic capacities, whereas the second suggested that $\mathrm{Cd}$ and $\mathrm{Cu}$ contamination 


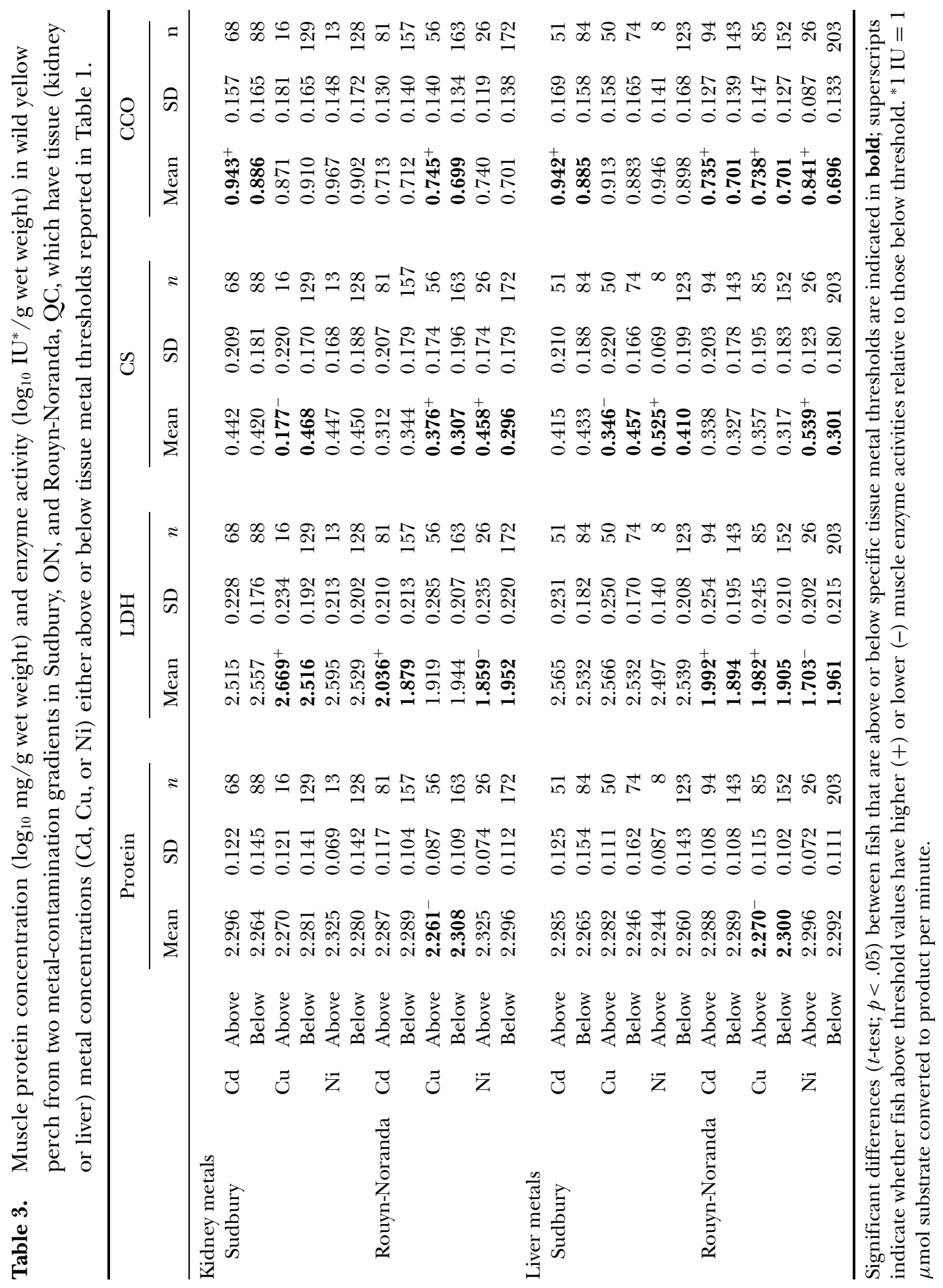




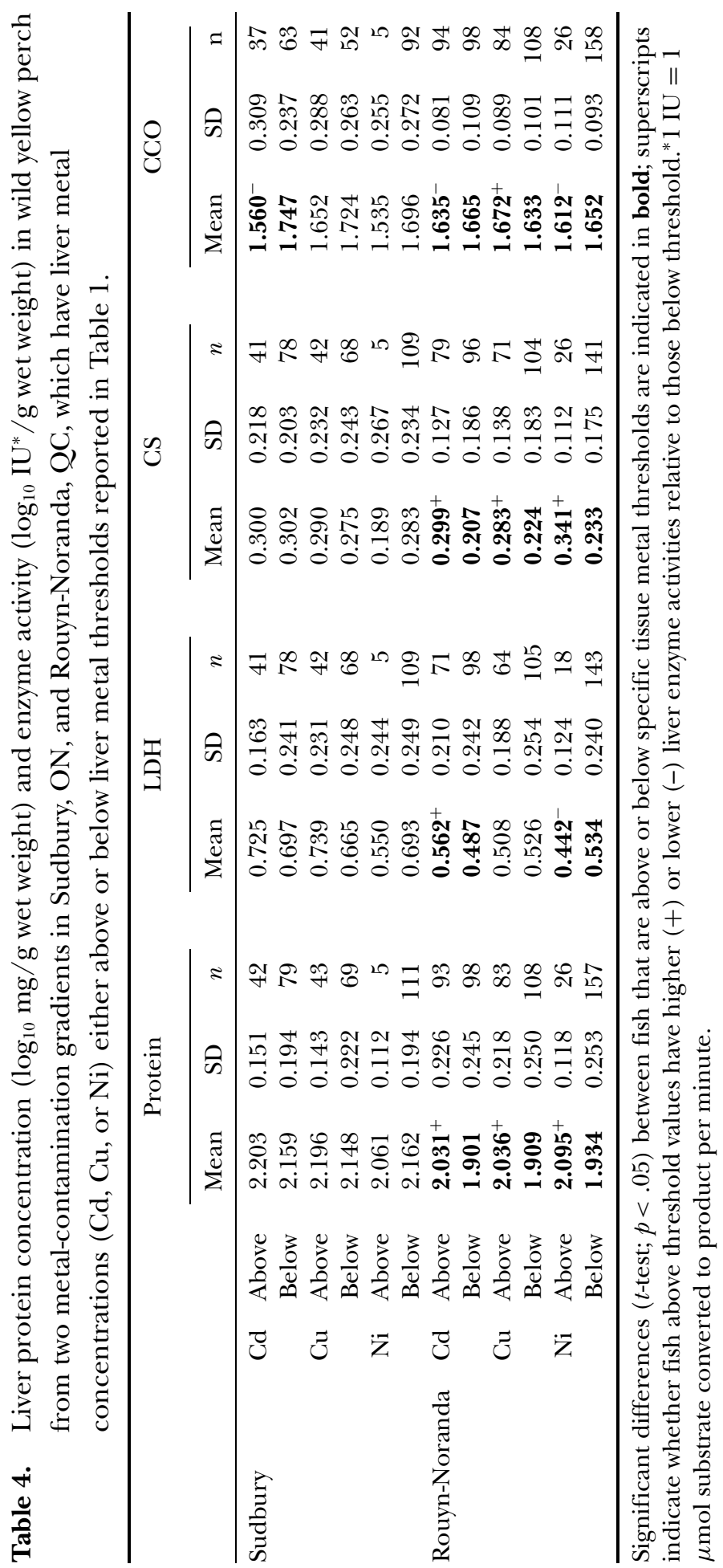




\section{P. Couture and G. Pyle}

was associated with increased liver and muscle LDH activities (Couture and Kumar 2003). The threshold approach used here in fish from two metal gradients provides a more complete perspective. In general, exceeding tissue metal thresholds did not affect muscle and liver $\mathrm{LDH}$ activities in S yellow perch, with the minor exception that excess kidney $\mathrm{Cu}$ was associated with higher liver and muscle $\mathrm{LDH}$ activities, in overall agreement with Rajotte and Couture (2002) and Couture and Kumar (2003). In contrast, $\mathrm{RN}$ fish exceeding tissue $\mathrm{Cd}$ and $\mathrm{Cu}$ concentration thresholds generally expressed higher liver and muscle LDH activities, but exceeding Ni thresholds led to lower liver and muscle LDH activity. Muscle LDH activity in yellow perch has been used as an indicator of activity cost (Sherwood et al. 2002; Kaufman et al. 2006). Our data indicate that, at least for $\mathrm{RN}$ fish, metal contamination must be considered when LDH activity is used as an indicator of locomotion in contaminated yellow perch.

There is strong evidence, reviewed elsewhere (Couture et al. 2008b), of aerobic impairment in metal-contaminated yellow perch. The tissue metal threshold approach provides an opportunity to generalize our understanding of how metal contamination affects tissue aerobic capacities in yellow perch. Using this approach, there was no evidence that metals negatively affected muscle aerobic capacities in $\mathrm{S}$ fish, except for CS activity that was lower in Cu-contaminated fish (Table 3), as previously reported (Rajotte and Couture 2002; Audet and Couture 2003; Couture and Kumar 2003). Exceeding tissue metal thresholds was more generally associated with increased muscle enzyme activities, especially in RN fish, which expressed higher muscle CS activities when kidney $\mathrm{Cu}$ or Ni or liver Ni concentrations exceeded thresholds. Sudbury fish exceeding the liver Ni threshold also exhibited higher muscle CS activity. Exceeding tissue thresholds of Cd in fish from both regions, and $\mathrm{Cu}$ and $\mathrm{Ni}$ in RN fish, was also associated with higher muscle CCO activity. Therefore, although the reduction in aerobic capacities of $\mathrm{Cu}$-contaminated $\mathrm{S}$ fish reported in earlier studies using CS as an indicator is strongly demonstrated here using the threshold approach, by examining other metals and adding CCO as an additional indicator of aerobic capacities, we can conclude that aerobic capacities are generally increased in yellow perch muscle fibers, especially in RN fish. Aerobic capacities of whole fish, measured in S fish using swim performance tests (Rajotte and Couture 2002) or oxygen consumption rate at rest and post-exercise (Couture and Kumar 2003) are instead lower in metal-contaminated fish. If this is also the case for contaminated $\mathrm{RN}$ fish, then their increased tissue aerobic capacities could reflect metabolic costs of metals for repair and detoxification or direct mitochondrial damage. In turn, this metal-induced increase in aerobic enzyme capacities could be involved in the reduced longevity of these fish (see later). It is important to note that, while the threshold approach used here suggests higher CCO activities in fish contaminated with all three metals examined, straight correlations between tissue metals and CCO activity (data not shown) indicated inconsistent trends. This is likely because factors other than metals also affect tissue aerobic capacities. Whereas aerobic capacities are primarily affected by metals in fish above contamination thresholds, variations induced by other natural factors in cleaner fish weaken general correlations between tissue metal concentrations and CCO activity. The influence of ecological variables on yellow perch tissue metabolic capacities (locomotory activity and predation) has been briefly reviewed elsewhere (Couture et al. 2008b). 


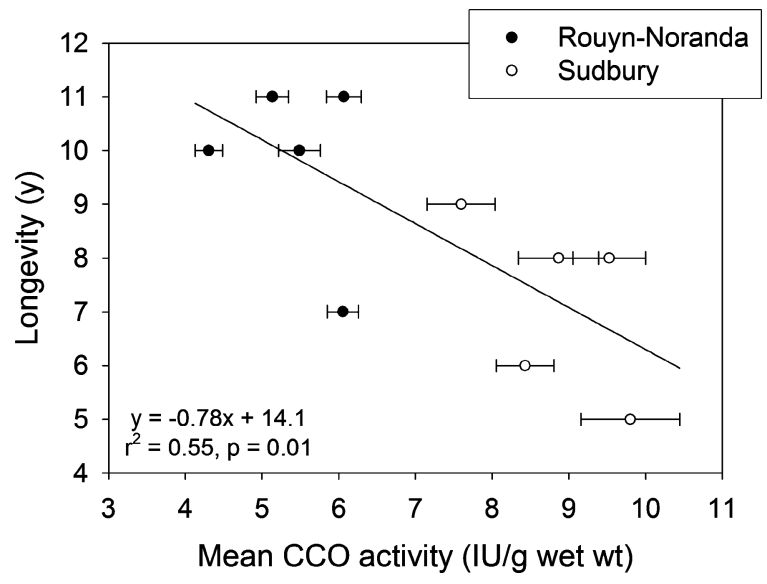

Figure 5. Relationship between muscle cytochrome $\mathrm{C}$ oxidase (CCO) activity and wild yellow perch longevity in 10 lakes comprising two metalcontamination gradients.

Although exceeding liver thresholds of all three metals examined led to increased liver $\mathrm{CS}$ activity and excess liver $\mathrm{Cu}$ enhanced liver $\mathrm{CCO}$ activity in RN fish (Table 4), in contrast to muscle, liver $\mathrm{Cd}$ and Ni contamination led to decreased liver CCO activities. Regional differences were much stronger for liver enzymes (Table 4) than for muscle enzymes (Table 3 ), because in $\mathrm{S}$ fish only one liver enzyme (CCO) was affected by one metal (Cd). Decreased CCO activities in the liver of $\mathrm{Cd}$ and $\mathrm{Ni}$ contaminated $\mathrm{RN}$ fish is an indication of uncompensated toxicity, again supporting a lower metal tolerance of RN compared to $\mathrm{S}$ fish.

Muscle CCO activity may have an influence on longevity. Increasing mean muscle CCO activities led to decreasing maximum age (as a surrogate for longevity) in wild yellow perch from each of the 10 lakes sampled, regardless of region Figure 5). Based on the significant equation of the linear relationship between longevity and muscle CCO activity, increasing muscle CCO from 4 to $11 \mathrm{IU} / \mathrm{g}$ (ww; i.e., the approximate range measured in this study representing a $64 \%$ increase) leads to a $55 \%$ reduction in longevity. In support of a metabolic cost for enhanced mitochondrial enzyme activity, increasing muscle CCO activity was also related to decreasing $K_{n}$ in all RN fish (see Figure 6 for an example in RN3; however, the effect was significant in all RN lakes and the slopes were not statistically different from each other) and near significant in S5 $(p=.06)$. We have speculated that $\mathrm{S}$ fish have probably adapted better metalregulatory processes to help cope with chronic metal exposure (Couture et al. 2008). It appears from the results reported earlier that $\mathrm{RN}$ fish are more susceptible to the negative influence of metal contamination on muscle CCO activity, probably because of their relatively inferior ability to regulate uptake and accumulation of dietary $\mathrm{Cu}$ and $\mathrm{Ni}$ relative to $\mathrm{S}$ fish.

Combining this evidence, we propose that exposure of yellow perch to elevated concentrations of metals over their lifetime leads to increases in mitochondrial respiration, which vary depending on evolved capacities for metal tolerance. Increased aerobic respiration in turn reduces longevity. In addition, our study indicates that adapting to metal tolerance or a faster growth rate in $\mathrm{S}$ fish also exerts a metabolic 


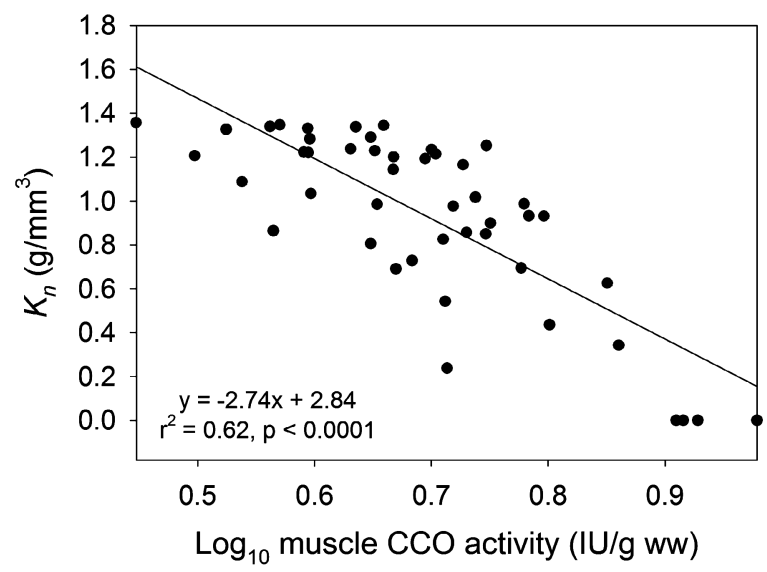

Figure 6. Relationship between muscle CCO activity and $K_{n}$ in wild yellow perch sampled from RN3 (Lac Bousquet) $(n=47)$.

cost. Indeed, as reviewed later, $\mathrm{S}$ fish grew faster, but died younger than $\mathrm{RN}$ fish as a whole. Consistent with this interpretation, muscle CCO and CS activities were also significantly higher in S compared to RN fish (data not shown), supporting that metal tolerance, longevity, and aerobic capacities may be linked. Although overall longevity was higher in $\mathrm{RN}$ fish, it was more negatively affected by metal contamination than in $\mathrm{S}$ fish. Metals have been reported in rats to damage mitochondrial membranes and increase their permeability (Garcia et al. 2000; Belyaeva and Korotkov 2003; Belyaeva et al. 2004). In addition, metallothionein, which is induced by cellular metal accumulation in several species including yellow perch (Giguère et al. 2005), has also been reported to increase inner membrane permeability of rat mitochondria (Simpkins $e t$ al. 1998). We do not know whether mitochondrial permeability is increased in metalcontaminated yellow perch, and if this would lead to compensatory increases in the activity of mitochondrial enzymes such as CS and CCO. However, a study of oxidative stress in RN yellow perch does not allow supporting that metal-contaminated fish are under significant oxidative stress (Giguère et al. 2005) although this hypothesis cannot be ruled out based on only one study in one region (RN) and one season (late spring) and that used a narrow set of indicators of metal stress (malondialdehyde and glutathione). Therefore, the relationships reported here between metal contamination, increased mitochondrial enzyme activity and longevity remain to be fully elucidated.

\section{GENERAL CONCLUSIONS}

Results from this study reveal that yellow perch are suitable for studying metal effects in wild populations that have experienced life-long metal exposures. However, in order to get at the complex relationships between metal accumulation and fish condition and metabolic capacities, a proper sampling design is required. The sampling design must be established with a focused research question in mind. If one is interested in understanding the relationship between metal accumulation 


\section{Metal Effects on Condition and Physiology of Wild Yellow Perch}

and metabolic effects or fish condition, then fish size must be considered in the design. Fish from comparative populations must be of the same size, or allometric corrections must be made prior to interpreting results. Seasonal variations in condition and metabolic capacities also necessitate that fish from comparative populations must be sampled within a narrow temporal window in order to minimize significant seasonal effects, and sampling repeated at least once in another season of the same year to capture seasonal variability in the parameters under investigation. In either case, the most important consideration is choosing adequate reference populations. Our results clearly demonstrate that sampling a single reference site is not suitable for drawing conclusions on metal accumulation patterns, fish growth and condition, or metabolic capacities. Suitable reference sites should be in close proximity to contaminated sites to maximize the probability that comparative populations have a similar genetic constituency, and minimize any significant regional effects. Moreover, because of myriad competing influences of non-target variables (e.g., temperature, water chemistry, competition, predation) any attempt to maximize reference-population variability among target variables by sampling more than one reference site will ultimately improve ERA predictions.

Similarly, sampling wild fish populations for a single indicator of metal effects provides little information. To understand the complex, yet subtle, influences of metal contamination on growth patterns or metabolic activities, study designs should consider more than one indicator variable. Fish growth is inextricably linked to fish physiology. Therefore, in any given population, when one variable is insensitive to metal contamination there is a greater likelihood of observing a subtle effect when more than one indicator variable is considered. Multivariate statistical analyses are encouraged for this sort of a study to consider all of the sources of variability (e.g., region, season, lake, fish size, several indicator variables), and their interrelationships, simultaneously.

Finally, this is one of the largest studies of its kind examining the complex relationships among sampling season and region, metal accumulation, fish growth and condition, and metabolic capacities on wild yellow perch. We have provided tissue metal accumulation thresholds for $\mathrm{Cd}$ and $\mathrm{Cu}$, and have demonstrated how tissue metabolic capacities are affected in fish that exceed those thresholds. Although metal-contaminated yellow perch do not appear impaired in their early growth, and even demonstrate higher growth rates than reference fish, their longevity is reduced. From this analysis, it appears that fish inhabiting metal-contaminated environments grow fast and die young, perhaps as a result of oxidative damage from up-regulated aerobic metabolic processes.

\section{ACKNOWLEDGMENTS}

This research was supported by a grant from the Metals in the Environment Research Network (Project C5) to PG and GP as well as by NSERC Discovery funding to PC. The authors thank the following people for their tireless efforts in the laboratory and field: Mehran Bakhtiari, Patrick Busby, Charles Gauthier, James Rajotte, Renée Stewart, and Joëlle Violette. The manuscript was greatly improved by useful comments from two anonymous referees. 


\section{P. Couture and G. Pyle}

\section{REFERENCES}

Audet D and Couture P. 2003. Seasonal variations in tissue metabolic capacities of yellow perch (Perca flavescens) from clean and metal-contaminated environments. Can J Fish Aquat Sci 60:269-78

Belyaeva EA and Korotkov SM. 2003. Mechanisms of primary $\mathrm{Cd}^{2+}$-induced rat liver mitochondria dysfunction: Discrete modes of $\mathrm{Cd}^{2+}$ action on calcium and thiol-dependent domains. Toxicol Appl Pharm 192:56-68

Belyaeva EA, Glazunov VV, and Korotkov SM. 2004. $\mathrm{Cd}^{2+}$-promoted mitochondrial permeability transition: A comparison with other heavy metals. Acta Biochim Pol 51:545-51

Bervoets L and Blust R. 2003. Metal concentrations in water, sediment and gudgeon (Gobio gobio) from a pollution gradient. Environ Pollut 126:9-19

Brodeur JC, Sherwood G, Rasmussen JB, et al. 1997. Impaired cortisol secretion in yellow perch (Perca flavescens) from lakes contaminated by heavy metals: In vivo and in vitro assessment. Can J Fish Aquat Sci 54:2752-8

Campbell PGC, Hontela A, Rasmussen JB, et al. 2003. Differentiating between direct (physiological) and food-chain mediated (bioenergetic) effects on fish in metal-impacted lakes. Hum Ecol Risk Asses 9:847-66

Campbell PGC, Giguere A, Bonneris E, et al. 2005. Cadmium-handling strategies in two chronically exposed indigenous freshwater organisms-the yellow perch (Perca flavescens) and the floater mollusc (Pyganodon grandis). Aquat Toxicol 72:83-97

Cone RS. 1989. The need to reconsider the use of condition indices in fishery science. Trans Am Fish Soc 118:510-4

Couture P and Kumar PR. 2003. Impairment of metabolic capacities in copper and cadmium contaminated wild yellow perch (Perca flavescens). Aquat Toxicol 64:107-20

Couture P and Rajotte JW. 2003. Morphometric and metabolic indicators of metal stress in wild yellow perch (Perca flavescens) from Sudbury, Ontario: A review. J Environ Monit 5:216-21

Couture P, Busby P, Rajotte J, et al. 2008a. Seasonal and regional variations of metal contamination and condition indicators in yellow perch (Perca flavescens) along two polymetallic gradients. I. Factors influencing tissue metal concentrations. Hum Ecol Risk Assess (this issue)

Couture P, Rajotte J, and Pyle G. 2008b. Seasonal and regional variations of metal contamination and condition indicators in yellow perch (Perca flavescens) along two polymetallic gradients. III. Energetic and physiological indicators. Hum Ecol Risk Assess (this issue)

Eastwood S and Couture P. 2002. Seasonal variations in condition and liver metal concentrations of yellow perch (Perca flavescens) from a metal-contaminated environment. Aquat Toxicol 58:43-56

Farkas A, Salanki J, and Specziar A. 2003. Age- and size-specific patterns of heavy metals in the organs of freshwater fish Abramis brama L. populating a low-contaminated site. Wat Res 37:959-64

Garcia N, Zazueta C, Carillo R, et al. 2000. Copper sensitizes the mitochondrial permeability transition to carboxytractyloside and oleate. Mol Cell Biochem 209:119-23

Giguere A, Campbell PGC, Hare L, et al. 2004. Influence of lake chemistry and fish age on cadmium, copper, and zinc concentrations in various organs of indigenous yellow perch (Perca flavescens). Can J Fish Aquat Sci 61:1702-16

Giguere A, Campbell P, Hare L, et al. 2005. Metal bioaccumulation and oxidative stress in yellow perch (Perca flavescens) collected from eight lakes along a metal contamination gradient (Cd, Cu, Zn, Ni). Can J Fish Aquat Sci 62:563-77

Hontela A, Daniel C, and Ricard AC. 1996. Effects of acute and subacute exposures to cadmium on the interrenal and thyroid function in rainbow trout, Oncorhynchus mykiss. Aquat Toxicol 35:171-82 


\section{Metal Effects on Condition and Physiology of Wild Yellow Perch}

Ion J, Lafontaine Y, Dumont P, et al. 1997. Contaminant levels in St. Lawrence River yellow perch (Perca flavescens): Spatial variation and implications for monitoring. Can J Fish Aquat Sci 54:2930-46

Kaufman SD, Gunn JM, Morgan GE, et al. 2006. Muscle enzymes reveal walleye (Sander vitreus) are less active when larger prey (cisco, Coregonus artedi) are present. Can J Fish Aquat Sci 63:970-9

Kraemer LD, Campbell PG, and Hare L. 2005. Dynamics of Cd, Cu and Zn accumulation in organs and sub-cellular fractions in field transplanted juvenile yellow perch (Perca flavescens). Environ Pollut 138:324-37

Kraemer LD, Campbell PG, Hare L, et al. 2006a. A field study examining the relative importance of food and water as sources of cadmium for juvenile yellow perch (Perca flavescens). Can J Fish Aquat Sci 63:549-57

Kraemer LD, Campbell PG, and Hare L. 2006b. Seasonal variations in hepatic Cd and Cu concentrations and in the sub-cellular distribution of these metals in juvenile yellow perch (Perca flavescens). Environ Pollut 142:313-25

Lacroix A and Hontela A. 2004. A comparative assessment of the adrenotoxic effects of cadmium in two teleost species, rainbow trout, Oncorhynchus mykiss, and yellow perch, Perca flavescens. Aquat Toxicol 67:13-21

Laflamme J-S, Couillard Y, Campbell PGC, et al. 2000. Interrenal metallothionein and cortisol secretion in relation to $\mathrm{Cd}, \mathrm{Cu}$, and $\mathrm{Zn}$ exposure in yellow perch, Perca flavescens, from Abitibi lakes. Can J Fish Aquat Sci 57:1692-700

Lambert Y and Dutil J. 1997. Can simple condition indices be used to monitor and quantify seasonal changes in the energy reserves of Atlantic cod (Gadus morhua) ? Can J Fish Aquat Sci 54:104-12

Le Cren ED. 1951. The length-weight relationship and seasonal cycle in gonad weight and condition in the perch (Perca fluviatilis). J Anim Ecol 20:201-19

Leis AL and Fox MG. 1994. Effect of mine tailings on the in situ survival of walleye (Stizostedion vitreum) eggs in a northern Ontario river. Ecoscience 1:215-22

Levesque HM, Moon TW, Campbell PG, et al. 2002. Seasonal variation in carbohydrate and lipid metabolism of yellow perch (Perca flavescens) chronically exposed to metals in the field. Aquat Toxicol 60:257-67

Levesque HM, Dorval J, Hontela A, et al. 2003. Hormonal, morphological, and physiological responses of yellow perch (Perca flavescens) to chronic environmental metal exposures. J Toxicol Environ Health 66:657-76

Lohner TW, Reash RJ, Willet VE, et al. 2001. Assessment of tolerant sunfish populations (Lepomis sp.) inhabiting selenium-laden coal ash effluents. 3. Serum chemistry and fish health indicators. Ecotoxicol Environ Saf 50:225-32

OMEE (Ontario Ministry of Environment and Energy). 1994. Provincial Water Quality Objectives. Queens Printer of Ontario, Toronto, ON, Canada

Patterson KR. 1992. An improved method for studying the condition of fish, with an example using Pacific sardine Sardinops sagax (Jenyns). J Fish Biol 40:821-31

Pyle G, Busby P, Gauthier C, et al. 2008. Seasonal and regional variations of metal contamination and condition indicators in yellow perch (Perca flavescens) along two polymetallic gradients. II. Growth patterns, longevity, and condition. Hum Ecol Risk Assess (this issue)

Pyle GG, Rajotte JW, and Couture P. 2005. Effects of industrial metals on wild fish populations along a metal contamination gradient. Ecotoxicol Environ Saf 61:287-312

Rajotte JW and Couture P. 2002. Effects of environmental metal contamination on the condition, swimming performance, and tissue metabolic capacities of wild yellow perch (Perca flavescens). Can J Fish Aquat Sci 59:1296-304 


\section{P. Couture and G. Pyle}

Sherwood GD, Rasmussen DJ, Rowan DJ, et al. 2000. Bioenergetic costs of heavy metal exposure in yellow perch (Perca flavescens): In situ estimates with a radiotracer $\left({ }^{137} \mathrm{Cs}\right)$ technique. Can J Fish Aquat Sci 57:441-50

Sherwood GD, Kovecses J, Hontela A, et al. 2002. Simplified food webs lead to energetic bottlenecks in polluted lakes. Can J Fish Aquat Sci 59:1-5

Simpkins C, Lloyd T, Li S, et al. 1998. Metallothionein-induced increase in mitochondrial inner membrane permeability. J Surg Res 75:30-4

Smith RW, Blaney SC, Dowling K, et al. 2001. Protein synthesis costs could account for the tissuespecific effects of sub-lethal copper on protein synthesis in rainbow trout (Oncorhynchus mykiss). Aquat Toxicol 53:265-77

Sorensen EMB. 1991. Metal Poisoning in Fish. CRC Press, Boca Raton, FL, USA

Wilson CC and Hebert PDN. Phylogeographic origins of lake trout (Salvelinus namaycush) in eastern North America. Can J Fish Aquat Sci 53:2764-75

Wilson CC and Hebert PDN. 1998. Phylogeography and postglacial dispersal of lake trout (Salvelinus namaycush) in North America. Can J Fish Aquat Sci 55:1010-24 
Copyright of Human \& Ecological Risk Assessment is the property of Taylor \& Francis Ltd and its content may not be copied or emailed to multiple sites or posted to a listserv without the copyright holder's express written permission. However, users may print, download, or email articles for individual use. 